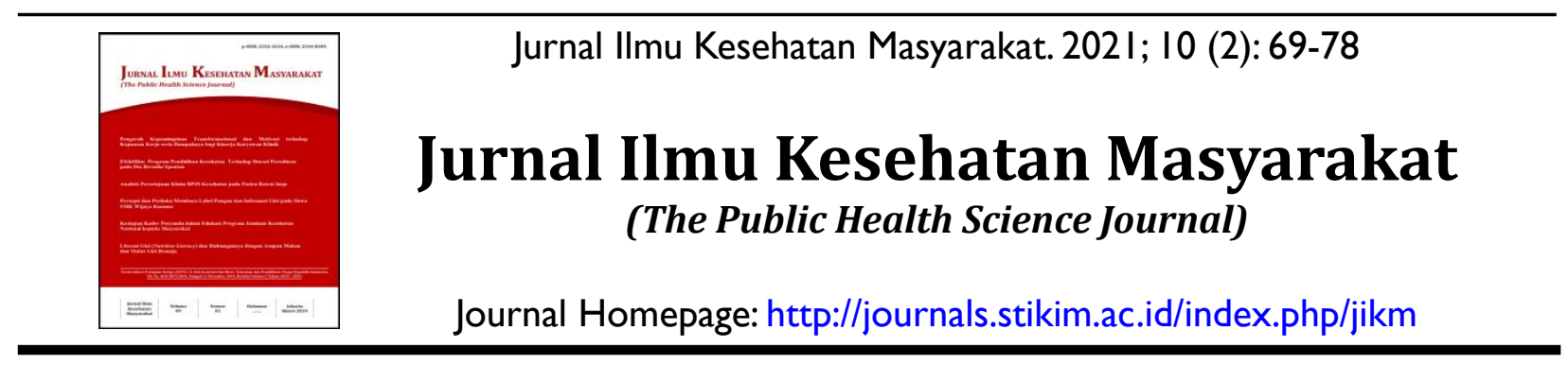

\title{
Analisis Penerapan Proteksi Kebakaran terhadap Kerentanan Anak Sekolah di DKI Jakarta Tahun 2019
}

\author{
Lulus S Hendrawati ${ }^{1}$, Husen ${ }^{2}$, Agung Cahyono ${ }^{3}$ \\ 1-3Program Studi Keselamatan dan Kesehatan Kerja, Universitas Binawan, Jakarta \\ Jln. Dewi Sartika RT.12/RW.5 Cawang, Kec. Kramat Jati, Jakarta Timur \\ Email: lulus@binawan.ac.id!
}

\begin{abstract}
Abstrak
Gedung sekolah merupakan sarana penting dalam proses pembelajaran anak-anak Indonesia. Dalam hal ini manajemen memiliki kewajiban untuk menjaga gedung sekolah dari kemungkinan terjadinya bencana, salah satunya adalah bencana kebakaran. Data kejadian kebakaran di Jakarta pada tahun 2018 masih cukup tinggi dengan jumlah kejadian 692 kejadian 6348 jiwa mengungsi. Maka penellitian ini bertujuan untuk mengetahui bagaimana penerapan proteksi kebakaran yang telah dilaksnakan di SDN 09 Makasar, Jakarta Timur. Metode Penelitian menggunakan desain kualitatif dengan Informan penelitian ini yaitu Kepala sekolah, guru, staf administrasi dan security, menggunakan data primer, instrument yang digunakan dengan wawan cara mendalam dan observasi lapangan. Hasil dari penelitian ini menunjukkan bahwa penerapan proteksi kebakaran di SDN 09 Makasar, Jakarta Timur masih belum terprogram dengan baik. Tenaga pendidik dan kependidikan belum pernah mengikuti pelatihan proteksi kebakaran dan sosialisai program pencegahan kebakaran sehingga mereka tidak memiliki kemampuan menggunakan alat proteksi kebakaran. Selain itu, belum adanya sistem proteksi kebakaran yang digunakan untuk pencegahan kebakaran pada bangunan gedung, berdampak terhadap keselamatan anak-anak yang menjadi siswa di sekolah tersebut.
\end{abstract}

Kata Kunci: Anak, kebakaran, proteksi, sekolah dasar, sistem.

\section{Abstract}

The school building is an important facility in the learning process of Indonesian children. In this case the management has an obligation to protect the school building from possible disasters. One of the disasters that can occur in the school building is a fire disaster. The data on fire incidents that happened in Jakarta 2018 are still quite high. There are 692 incidents happened and 6348 people were displaced (Recapitulation data of Fire Events in DKI Jakarta, 2019). So, this research aims is to find out how the application of fire protection has been carried out at SDN 09 Makassar, East Jakarta.This research use qualitative research with the informants of this study, namely the principal, teachers, administrative and security staff, using primary data, the instruments used were interviews and field observations. The results of this study indicate that the application of fire protection at SDN 09 Makasar, East Jakarta is still not well programmed. Educators and education personnel have never attended fire protection training and socialization of fire prevention so they do not have the ability to use fire protection equipment. In addition of that, there is no fire protection system used for fire prevention in buildings, which has an impact on the safety of children who are students at the school.

Keywords: Children, fire, protection, elementary school, system. 


\section{Pendahuluan}

Gedung sekolah merupakan sarana penting dalam proses pembelajaran anak-anak Indonesia dalam menuntut ilmu pengetahuan di sekolah, sehingga manajemen memiliki kewajiban dalam menjaga gedung sekolah dari kemungkinan terjadinya bencana, salah satunya adalah bencana. ${ }^{1}$ Data kejadian kebakaran menurut manajemen keselamatan kebakaran gedung (BMKG) Provinsi DKI di Jakarta pada tahun 2018 masih cukup tinggi dengan jumlah kejadian 692 kejadian dengan korban jiwa meninggal sebanyak 25 jiwa, luka berat sebanyak 23 jiwa dan luka ringan sebanyak 159 jiwa serta ada sekitar 6348 jiwa mengungsi. ${ }^{2}$ Peristiwa kejadian kebakaran juga pernah terjadi di salah satu gedung sekolah yaitu Sekolah Diponegoro, Jakarta Timur karena adanya konsleting listrik. ${ }^{3}$

Penilaian risiko bahaya kebakaran perlu ditanamkan sejak dini, termasuk anak usia sekolah dasar. Pada usia ini, kesadaran akan keselamatan kebakaran dapat tertanam dan melekat dalam ingatan anak-anak sehingga mereka dapat menerapkannya tidak hanya di sekolah tetapi juga di rumah. Selain itu anak-anak di sekolah dasar (SD) merupakan periode emas (golden age), dimana telah diketahui bahwa sekolah merupakan target utama program pencegahan dan penanggulangan kebakaran. Kebakaran gedung bertingkat di Indonesia merupakan masalah yang harus ditangani secara serius. ${ }^{4}$

Pendidikan dini mitigasi bencana kebakaran merupakan hal yang penting bagi manajemen sekolah di Jakarta karena sebagian besar gedung sekolah terletak di wilayah perkampungan padat penduduk. Letak gedung sekolah yang dekat dengan wilayah perkampungan padat penduduk, menyebabkan apabila terjadi peristiwa kebakaran akan mempercepat merembetnya api dari sekolah ke rumah-rumah penduduk di sekitarnya ataupun sebaliknya, apabila di rumah penduduk di sekitar gedung sekolah mengalami kejadian kebakaran akan berpotensi merembet ke gedung sekolah yang ada di sekitarnya. Penerapan sistem mitigasi bencana kebakaran sangat membutuhkan kesiapan sumber daya dan sarana prasarana. Kesiapan dalam menghadapi kejadian kebakaran terlebih dahulu harus dilakukan sebuah penilaian risiko terhadap kebakaran dan dilakukan rencana pengendalian kebakaran pada gedung sekolah. ${ }^{5}$

Dari penelitian Arief Kurniawan, rata-rata proteksi aktif di gedung Fakultas Kedokteran dan Ilmu Kesehatan (FKIK) cukup baik artinya terpasang tapi ada beberapa sarana proteksi aktif yang belum terpasang dan ada yang tidak sesuai dengan peraturan perundangan $(74,4 \%){ }^{6}$ penelitian tersebut juga menyebutkan bahwa rata-rata sarana penyelamat jiwa di gedung FKIK dalam kategori cukup artinya terpasang, tapi ada beberapa sarana penyelamat jiwa yang belum terpasang dan ada yang tidak sesuai dengan peraturan perundangan $(76,25 \%){ }^{6}$ Menurut Penelitian Fatma Lestari, dkk Kajian Keselamatan kebakaran di 5 SDN di DKI Jakarta menunjukan bahwa seluruh sekolah belum memiliki APAR dan hydran. ${ }^{7}$ Penelitian tersebut menyebutkan bahwa sumber air lainnya yang terdekat ditemui di 4 SDN yang diamati sementara 1 SDN tidak memiliki sumber air lainnya.

Berdasarkan hasil survei pendahuluan di SD 09 Makasar Kecamatan Makasar Jakarta Timur terlihat bahwa letak bangunan sekolah sangat dekat dengan perkampungan penduduk, maka ada kemungkinan apabila terjadi kebakaran akan dapat merembet ke wilayah yang bersebelahan dengan lokasi peristiwa kebakaran ataupun sebaliknya. Selain khawatir akan kondisi bangunan yang memiliki kemungkinan terkena dampak kebakaran, para staf SD juga mengkhawatirkan keselamatan anak sekolah yang rata-rata masih berusia 7-12 tahun dimana usia ini merupakan usia rentan terhadap kejadian bencana termasuk bencana kebakaran. Tujuan penelitian ini adalah untuk mengetahui penerapan sistem proteksi kebakaran pada gedung Sekolah Dasar di Jakarta Timur yang diharapkan dapat memberi gambaran sejauh mana penanganan terhadap kejadian kebakaran 
yang mungkin terjadi di gedung sekolah.

\section{Metode}

Penelitian ini adalah penelitian kualitatif dengan pendekatan observasional dan wawancara mendalam. Pendekatan ini dipilih terkait dengan tujuan penelitian untuk membangun konsep penanggulangan bencana kebakaran yang dilaksanakan di SD 09 Makasar Kecamatan Makasar Jakarta Timur. Konsep ini dibangun melalui penerapan Emergency response system oleh pengelola sekolah. Penelitian ini dilaksanakan dari bulan Juni-September 2019. Informan yang dilakukan wawancara yaitu tenaga pendidik dan kependidikan (kepala sekolah, 1 guru, 1 staf administrasi dan 1 security). Pengumpulan data dilakukan dengan wawancara mendalam dan observasi. Instrumen yang digunakan yaitu pedoman wawancara mendalam dan lembar observasi lapangan. Data yang digunakan yaitu data primer, dalam bentuk hasil wawancara secara lisan, gerak-gerik atau perilaku yang dilakukan oleh subjek yang dapat dipercaya dan data sekunder seperti pendokumentasi alat-alat pemadam kebakaran yang ada di sekolah SD 09 makasar dan kebijakan-kebijakan mengenai pemandam kebakaran. Analisis data dilakukan secara induktif, dimana penelitian tidak dimulai dari teori, melainkan fakta empirik di lapangan. Peneliti terjun langsung ke lapangan, mempelajari, menganalisa, dan menarik kesimpulan terhadap apa yang terjadi di lapangan.

\section{Hasil dan Pembahasan}

Karakteristik informan

\begin{tabular}{clcccc}
\hline Kode Informan & \multicolumn{1}{c}{ Informan } & Usia & Pendidikan & Jenis Kelamin & Jenis Informan \\
\hline 1 & Kepala Sekolah & 58 & $\mathrm{~S} 1$ & $\mathrm{P}$ & Informan utama \\
2 & Guru & 53 & $\mathrm{~S} 1$ & $\mathrm{P}$ & Informan pendukung \\
3 & Staf Administrasi & 32 & $\mathrm{~S} 1$ & $\mathrm{P}$ & Informan pendukung \\
4 & Security & 48 & SMA & $\mathrm{L}$ & Informan kunci \\
\hline
\end{tabular}

Informan utama dari penelitian ini adalah kepala sekolah yang merupakan penentu kebijakan di SDN 09 Makasar. Sedangkan informan pendukung dalam penelitian ini adalah tiga orang staf yang terdiri dari guru, staf administrasi dan security yang berperan sebagai pelaksana lapangan.

\section{Gambaran sistem proteksi kebakaran di gedung SDN 09 Makasar}

Gedung sekolah tersebut tidak memiliki APAR, hidran, alarm kebakaran dan sistem detektor asap. Pihak manajemen tidak memiliki stiker atau tanda peringatan kebakaran di dinding gedung atau di tempat yang mudah diakses oleh penghuni gedung seperti teras dan halaman sekolah dalam bentuk leaflet atau banner. Tidak ada pintu darurat, tangga darurat, titik kumpul dan tanda petunjuk arah apabila terjadi bencana kebakaran. Gedung sekolah tidak memiliki pintu darurat dan tangga darurat, mereka hanya memanfaatkan tangga akses turun naik dari lantai satu ke lantai dua yang tidak standar sebagai tangga darurat sesuai dengan peraturan.

Di gedung sekolah di SDN 09 Makasar terdapat tangga yang digunakan untuk naik dan turun dari dan ke lantai 1 (satu) dan juga berfungsi sebagai tangga darurat apabila terjadi kebakaran di gedung sekolah tersebut yang belum sesuai dengan ketentuan Permen PU No. 26 Tahun 2008 tentang persyaratan teknis sistem proteksi kebakaran pada bangunan gedung dan lingkungan, yang syarat utamanya adalah letak tangga harus terpisah dari tangga terbuka atau tangga aktifitas karena tangga darurat harus memiliki dinding pelindung sehingga orang yang melintas akan terlindung dari kobaran api. 
Setiap bangunan gedung bertingkat harus dilengkapi dengan petunjuk jalur evakuasi untuk penanganan evakuasi penghuni gedung apabila terjadi bencana terutama bencana kebakaran. Ketentuan ini tertuang dalam Permen PU No. 26 Tahun 2008 tentang persyaratan teknis sistem proteksi kebakaran pada bangunan gedung dan lingkungan. Fungsinya adalah untuk mempermudah penghuni gedung menemukan jalan untuk menyelamatan diri apabila terjadi bencana kebakaran. Sehingga akan terhindar dari kondisi yang memungkinkan penghuni gedung terperangkap api di dalam gedung. Kondisi ini bisa terjadi karena tidak ada tanda yang dapat menunjukan dimana jalur evakuasi berada. Namun pada gambar 1 dapat dilihat bahwa tidak ada tanda petunjuk jalur evakuasi di gedung SDN 09 Makasar yang seharusnya diletakkan pada dinding sekitar tangga sekolah.

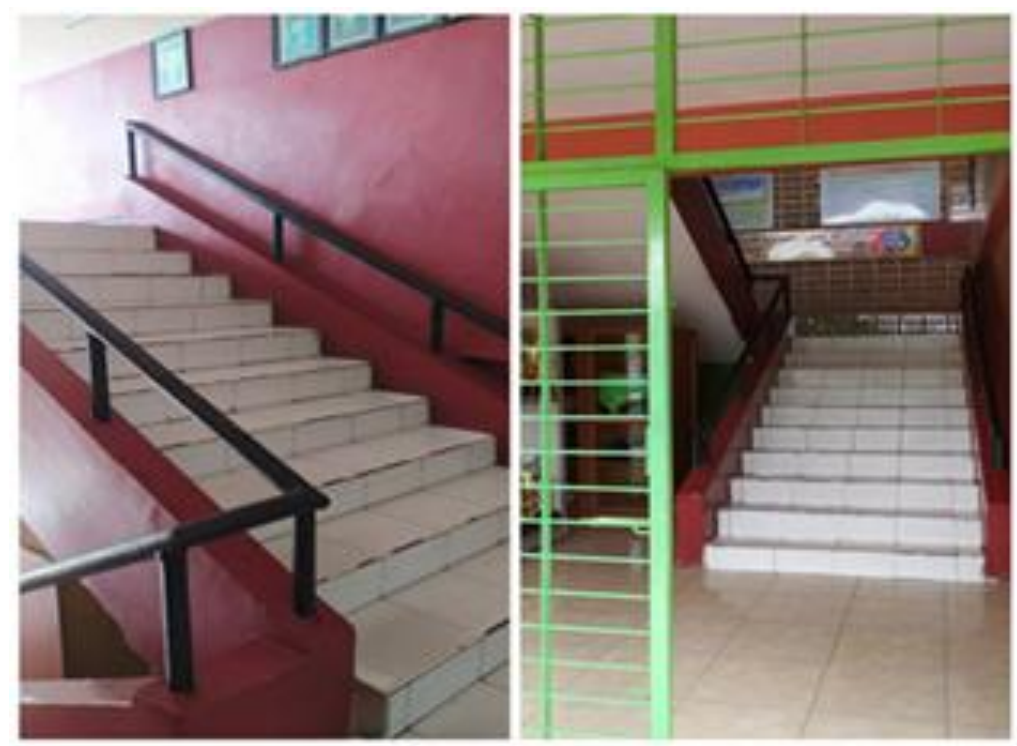

Gambar 1. Tangga Gedung SDN 09 Makasar

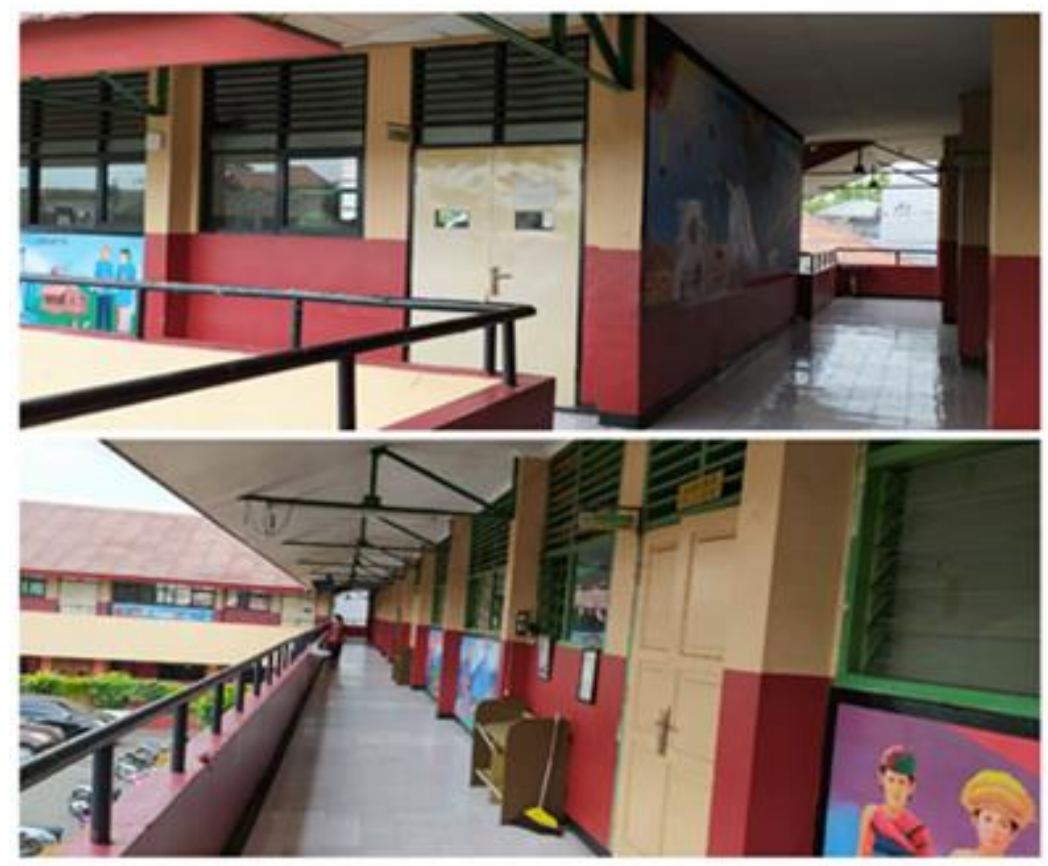

Gambar 2. Gedung SDN 09 Makasar lantai 2 
Gedung SDN 09 Makasar, Jakarta Timur tidak memiliki alat proteksi kebakaran seperti APAR, hidran, alarm kebakaran dan sistem detektor asap. Kondisi ini tidak sesuai dengan persyaratan yang ditetapkan oleh Permen PU No. 26 Tahun 2008 tentang persyaratan teknis sistem proteksi kebakaran pada bangunan gedung dan lingkungan. Dalam peraturan ini terdapat ketentuan bahwa peletakan alat proteksi kebakaran seperti APAR yang harus diletakkan di tempat yang mudah dilihat dan mudah dijangkau yaitu minimal 1,5 meter dari lantai. Karena dengan tidak adanya sistem proteksi kebakaran aktif di gedung bertingkat akan meningkatkan risiko terjadinya kejadian kebakaran yang lebih besar. Alat proteksi kebakaran ini digunakan oleh manajemen gedung sekolah untuk dapat melakukan pemadaman api segera apabila di gedung sekolah atau di lingkungan sekitar terjadi kebakaran sehingga akan mencegah perluasan api agar tidak menyambar ke lingkungan sekitarnya

\section{Pelatihan Tanggap Darurat Kebakaran}

Pada tahap identifikasi tentang kebutuhan pelatihan tanggap darurat kebakaran di SDN 09 Makasar, masing-masing staf tidak ada yang mengikuti pelatihan tanggap darurat kebakaran karena belum ada program dari pihak Dinas Pendidikan setempat. Hal ini sesuai dengan apa yang disampaikan oleh infroman sebagai berikut :

"Belum pernah mengikuti pelatihan tanggap darurat kebakaran baik yang diselenggarakan oleh pemerintah daerah, Dinas pemadam kebakaran daerah maupun oleh Dinas Pendidikan daerah". (Informan 1)

Program pelatihan tanggap darurat kebakaran juga belum pernah dilaksanakan oleh pihak sekolah sehingga para staf sekolah belum pernah mengikuti kegiatan tersebut selama menjadi staf di SDN 09 Makasar.
"Belum pernah ikut dalam kegiatan pelatihan tanggap darurat kebakaran yang diselenggarakan oleh pihak luar sekolah dan SDN 09 Makasar, Jakarta Timur sendiri juga belum pernah melaksanakan kegiatan pelatihan tangga darurat kebakaran". (Informan 2)

"Belum pernah ikut dalam kegiatan pelatihan tentang kebakaran selama bekerja di SDN 09 Makasar, Jakarta Timur dan pihak sekolah juga belum pernah menyelenggaraka pelatihan kebakaran untuk staf sekolah". (Informan 3)

Meskipun program pelatihan tanggap darurat kebakaran belum pernah dilaksanakan oleh pihak sekolah, para staf bisa saja mengikuti pelatihan tanggap darurat kebakaran di instansi lain yang menyelenggarakannya.

"Pernah mengikuti pelatihan tanggap darurat kebakaran di tempat kerja lama sebelum bekerja menjadi security di SDN 09 Maksar, Jakarta Timur" tapi selama menjadi security di sekolah ini, belum pernah mengikuti pelatihan lagi”. (Informan 4)

Dari hasil wawancara terhadap keempat informan dapat diketahui bahwa pihak Dinas Pendidikan DKI Jakarta belum pernah membuat program untuk melaksanakan kegiatan pelatihan tanggap darurat kebakaran di SDN 09 Makasar, Jakarta Timur. Belum adanya program kegiatan pelatihan tanggap darurat kebakaran yang dibuat oleh Dinas Pendidikan DKI Jakarta tersebut menunjukkan bahwa seluruh staf kecuali security belum pernah mengikuti kegiatan pelatihan tanggap darurat kebakaran yang diperlukan untuk penanggulangan kejadian kebakaran di sekolah dan lingkungan sekitar sekolah.

Berdasarkan Standar NFPA 101 tentang life safety code dan Kepmen Kep. 186/Men/1999 tentang unit penanggulangan kebakaran, maka pelatihan tanggap darurat kebakaran bagi tenaga pendidik dan kependidikan sangat penting yang harus diprogramkan oleh Pemerintah setempat ataupun pihak sekolah, karena apabila 
semua tenaga pendidik dan kependidikan memiliki pengetahuan dan keterampilan dalam bidang tanggap darurat kebakaran maka akan mempermudah staf sekolah dalam menghadapi risiko kebakaran di sekolah. Hal ini akan mempermudah para staf, terutama security yang menjaga gedung sekolah 24 jam sehari, maka dibutuhkan kemampuan dalam menentukan langkah-langkah atau tahapan apa yang akan mereka lakukan apabila terjadi bencana kebakaran di sekolah dan lingkungan sekitarnya dengan baik.

\section{Simulasi Kebakaran:}

Adapun dalam hal pelaksanaan kegiatan simulasi kebakaran di gedung SDN 09 Makasar, pihak sekolah belum pernah mengadakan kegiatan simulasi kebakaran gedung sekolah yang diadakan bersama dengan pihak Dinas Pemadam Kebakaran dan Penyelamatan atau Perangkat Daerah DKI Jakarta untuk SDN 09 Makasar. Hal ini sesuai dengan apa yang disampaikan oleh informan sebagai berikut :

\begin{abstract}
"Belum pernah mengadakan kegiatan simulasi kebakaran gedung sekolah karena belum ada permintaan dari pihak sekolah kepada Dinas Pemadam Kebakaran dan Penyelamatan atau Perangkat Daerah yang menyelenggarakan sub urusan kebakaran ataupun sebaliknya”. (Informan 1)
\end{abstract}

Pelaksanaan kegiatan simulasi kebakaran yang belum pernah diadakan di sekolah SDN 09 Makasar, mengakibatkan para staf sekolah belum pernah ada yang mengikuti kegiatan simulasi kebakaran selama menjadi staf di SDN 09 Makasar.

\footnotetext{
"Belum pernah mengikuti kegiatan simulasi kebakaran karena belum pernah diadakan kegiatan simulasi kebakaran di SDN 09 Makasar, Jakarta Timur”. (Informan 2)

"Pihak sekolah belum pernah melakukan kegiatan simulasi kebakaran jadi belum pernah melakukan kegiatan simulasi kebakaran". (Informan 3)

"Selama bekerja sebagai security di SDN 09 Makasar, belum pernah mengikuti kegiatan simulasi gedung sekolah”. (Informan 4)
}

Dari hasil wawancara keempat informan diketahui bahwa sekolah SDN 09 Makasar belum pernah melakukan kegiatan simulasi kebakaran gedung sekolah sehingga para staf juga belum pernah mengikuti kegiatan simulasi kebakaran gedung yang biasanya diselenggarakan oleh Dinas Pemadam Kebakaran dan Penyelamatan atau Perangkat Daerah yang menyelenggarakan sub urusan kebakaran. Hal ini diperlukan dalam rangka program penerapan sistem proteksi kebakaran di gedung sekolah untuk menurun tingkat kerentanan anak dari kejadian bencana kebakaran di sekolah.

Salah satu bagian dari sistem proteksi kebakaran adalah keterampilan seseorang yang mampu mensimulasikan bagimana cara memadamkan kebakaran, melakukan penyelamatan diri sendiri dan membantu penghuni gedung yang lain untuk dapat selamat dari kejadian bencana kebakaran. Hal ini tentu akan baik apabila seluruh tenaga pendidik dan kependidikan mampu melakukan memadamkan api kebakaran yang belum terlalu besar sehingga api tidak menyebar ke lingkungan sekitar gedung terutama kerumah penduduk yang sangat berdekatan dengan gedung sekolah. Dengan adanya kegiatan simulasi diharapkan para staf sekolah SDN 09 Makasar dapat juga menjaga keselamatan para siswa yang mejadi penghuni terbesar di sekolah tersebut.

Menurut peraturan Permendagri Nomor 114 Tahun 2019 tentang Standar Teknis Pelayanan Dasar Pada Standar Pelayanan Minimal Sub Urusan Kebakaran Daerah Kabupaten/Kota yang salah satu isinya adalah tentang pelatihan/simulasi dan penyuluhan masyarakat relawan kebakaran, maka wajib bagi pihak sekolah SDN 09 Makasar untuk melaksanakan kegiatan simulasi kebakaran gedung karena gedung SDN 09 Makasar terdiri dari dua tingkat yang posisi ruangannya ada di tingkat dua diatas gedung SDN 08 Makasar, Jakarta Timur. 
Pengoperasian Alat Proteksi Kebakaran

Dalam hal pengoperasian alat proteksi kebakaran para staf yang terdiri dari wakil kepala sekolah, guru dan staf administrasi SDN 09 Makasar tidak memiliki pengetahuan bagaimana cara mengoperasikan alat proteksi kebakaran karena masing-masing staf belum pernah mengikuti pelatihan tentang cara pengoperasian alat proteksi kebakaran. Pada tahap identifikasi tentang kebutuhan pelatihan tanggap darurat kebakaran di SDN. Hal ini sesuai dengan apa yang disampaikan oleh infroman sebagai berikut.

"Para staf belum dapat menggunaan alat
proteksi kebakaran karena pihak sekolah
tidak memiliki alat proteksi kebakaran dan
juga belum pernah ada program bagi staf
untuk mengikuti pelatihan tentang
penggunaan alat proteksi kebakaran".
(Informan 1)

Kondisi gedung sekolah SDN 09 Makasar yang tidak memiliki alat proteksi kebakaran mengakibatkan para staf tidak dapat mengoperasikan alat-alat proteksi kebakaran seperti APAR, Hidran dan lain-lain.

"Tidak bisa menggunakan APAR, Hidran dan lain-lain karena belum pernah latihan menggunakannya dan sekolah juga tidak memilikinya”. (Informan 2)

"Tidak bisa menggunakan alat proteksi kebakaran karena sekolah tidak punya alat-alat tersebut”. (Informan 3)

Ketrampilan penggunaan alat proteksi kebakaran tetap harus dimiliki oleh penanggungjawab gedung karena dapat digunakan apabila gedung dalam situasi terjadi kejadian kebakaran.

"Bisa mengoperasikan alat proteksi kebakaran karena sudah pernah belajar ketika mengikuti pelatihan tentang tanggap darurat kebakaran tetapi secara langsung belum pernah menggunakan dalam kondisi terjadi kebakaran yang sesungguhnya". (Informan 4)
Menurut SNI 03-1735-2000 tentang Tata Cara Perencanaan Akses Bangunan dan Akses Lingkungan untuk Pencegahan Kebakaran pada Bangunan Gedung yang didalamnya juga berisi tentang sistem proteksi kebakaran. Di dalam aturan tersebut juga membahas tentang kewajiban pemilik gedung untuk menyediakan alat proteksi kebakaran dan bagaimana mengoperasiannya. Staf sekolah selaku pihak yang memiliki tanggung jawab untuk mengelola gedung sekolah harus dibekali dengan keterampilan dalam mengoperasikan alat proteksi kebakaran aktif seperti APAR, hidran, springkler dan alat proteksi lainnya.

Kemampuan seseorang yang dapat mengoprasionalkan alat proteksi kebakaran harus dibarengi dengan pengadaan alat proteksi kebakata itu sendiri. Jika sebuah gedung memiliki alat proteksi akan mempermudah mereka dalam melakukan simulasi penggunaan alat proteksi kebakaran untuk mencegah apabila terjadi kemungkinan kejadian kebakaran di gedung sekolah dan lingkungan sekitarnya. Sekolah SDN 09 Makasar perlu memberi bekal keterampilan penggunaan alat proteksi kebakaran kepada para stafnya agar mereka dapat melindungi anak sekolah yang menjadi siswa di sekolah tersebut dan juga dapat mengurangi tingkat kerentanan anak dari kejadian kebakaran yang mungkin terjadi di sekolah tersebut.

\section{Sarana dan Prasarana Sistem Proteksi Kebakaran}

Dalam hal kelengkapan sarana dan prasarana sistem proteksi kebakaran di gedung SDN 09 Makasar, diketahui bahwa untuk kelengkapan alat-alat proteksi kebakaran masih sangat kurang. Dari 8 persyaratan yang harus dipenuhi baru ada 3 persyaratan yang terpenuhi baik dari segi ketersediaan alat maupun sistem perawatannya. Hal ini sesuai dengan apa yang disampaikan oleh infroman sebagai berikut:

"Tersedia pasokan air karena ada sungai yang tidak jauh dari sekolahan, jalan menuju gedung sekolah bisa dilalui mobil pemadam 
apabila terjadi kebakaran, ada tangga yang digunakan naik turun gedung dari lantai satu dan lantai dua, gedung sekolah dibangun dengan menggunakan bahan batu bata dan jedela terbuat dari kaca, tidak ada alat proteksi kebakaran, Instalasi listrik gedung sudah baik, tidak ada pemasangan tanda keselamatan terpasang di dinding sekolah atau lingkungan sekitarnya." (Informan 4)

Sesuai dengan pengamatan peneliti di lingkungan gedung SDN 09 Makasar ditemukan kesamaan antara fakta di lapangan dengan apa yang disampaikan oleh informan kunci. Perlengkapan sarana dan prasarana proteksi kebakaran yang wajib dimiliki oleh gedung sekolah sesuai dengan peraturan PERMEN PU No: 20 Tahun 2009 Tentang Pedoman Teknis Manajemen Proteksi Kebakaran di Perkotaan belum sepenuhnya tersedia. Terdapat tiga persyaratan yang wajib dipenuhi oleh pihak gedung yaitu, prasarana proteksi kebakaran, sarana pencegahan kebakaran, dan sarana penanggulangan kebakaran. Prasarana proteksi kebakaran terdiri dari pasokan air, pemadam api bukan air, akses jalan untuk mobil pemadam, dan bangunan yang tahan terhadap api. Sarana pencegahan kebakaran berupa dokumen pedoman penanggulangan kebakaran dan tanda pencegahan kebakaran yang dipasang di dinding gedung sekolah dan lingkungan sekitarnya. Sarana penanggulangan kebakaran terdiri dari pengadaan kendaraan operasional pengendalian kebakaran, peralatak teknik penanggulangan kebakaraan dan alat untuk pertolongan pertama pada kejadian kecelakaan.

Perlengkapan sarana dan prasarana sistem proteksi kebakaran di SDN 09 Makasar secara keseluruhan masih berkisar $30 \%$ karena dari tiga ketentuan yang terdapat di PERMEN PU No: 20 Tahun 2009 baru terpenuhi satu ketentuan dan belum semua terpenuhi. Pada prasarana proteksi kebakaran, selain pasokan air yang dapat diambil dari aliran sungai, gedung sekolah juga wajib menyediakan tandon air yang mencukupi untuk penanggulangan kebakaran tingkat awal dan ini belum dimiliki gedung SDN 09 Makasar. Selain pasokan air sebagai bahan pemadam api, gedung sekolah juga harus menyediakan bahan pemadam bukan air yang dapat berupa foam atau bahan kimia lain, dan ini juga belum dimiliki oleh pihak sekolah. Selain beberapa persyaratan tadi, model bangunan gedung SDN 09 Makasar sudah sesuai dengan ketentuan PERMEN PU No: 20 Tahun 2009 yang didalamnya juga mengatur tentang model bangunan/fasilitas pendidikan.

Prasarana proteksi kebakaran di gedung sekolah SDN 09 Makasar yang terdiri dari bangunan tembok dengan jendela kaca yang tahan akan api sehingga dapat meminimalisir perembetan api ke seluruh bagian gedung sekolah. Sedangkan utilitas bangunan Gedung berupa instalasi listrik di gedung SDN 09 telah sesuai dengan SNI 04-0225-2000 tentang Persyaratan Umum Instalasi Listrik (PUIL) sehingga dapat mengurangi risiko kejadian kebakaran. Namun secara keseluruhan gedung SDN 09 Makasar masih belum memiliki sistem proteksi kebakaran dan juga memiliki Program Keselamatan Kebakarana (Fire Safety Housekeeping) sesuai dengan Permen PU No: 26 tahun 2008 tentang persyaratan teknis sistem proteksi kebakaran pada bangunan dan lingkungan, sehingga ini perlu dilakukan program pengadaan proteksi kebakaran aktif minimal Alat Pemadam Api Ringan (APAR) dan Hidran untuk menanggulagi apabila terjadi kejadian kebakaran di gedung SDN 09 Makasar. Pengelolaan sistem proteksi kebakaran pada bangunan gedung dibutuhkan keikutsertaan otoritas berwenang setempat (OBS).

SDN 09 Makasar memiliki 377 Siswa dengan usia rata-rata 7-13 Tahun dan masih termasuk usia rentan. Oleh karena itu, perlu dibuatkan sistem proteksi kebakaran gedung di SDN 09 Makasar, Jakarta Timur. Disamping itu perlu direncanakan menyusunan program lanjutan untuk pengelolaan sistem proteksi kebakaran untuk meningkatkan perlindungan terhadap siswa sekolah yang menjadi kelompok rentan bencana kebakaran dimana pada kondisi bencana anak-anak dengan 
karakteristiknya menjadi rentan terhadap dampak yang ditimbulkan oleh bencana. ${ }^{10}$

Anak-anak seringkali menjadi korban terbesar dalam setiap kejadian bencana karena tidak memiliki kemampuan untuk melindungi diri, anak-anak sering kali panik pada saat terjadi bencana dan belum memiliki kekuatan fisik untuk menyelamatan diri. Anak-anak yang masih butuh perlindungan orang tua juga butuh perlindungan orang yang lebih dewasa yaitu staf sekolah karena merekalah pengganti orang tua ketika anak-anak sedang melaksanakan proses belajar di sekolah. Ini artinya bahwa pihak pemerintah daerah dan juga sekolah tempat anak-anak melakukan proses belajar mengajar perlu mengadakan program pelatihan tanggap darurat kebakaran untuk staf sekolah dan kegiatan simulasi tanggap darurat bencana kebakaran untuk staf sekolah dan siswa SDN 09 Makasar. Kegiatan tersebut merupakan salah satu pelaksanaan penerapan sistem proteksi kebakaran sekolah yang nantinya digunakan untuk pencegahan dan juga penanggulangan kejadian kebakaran.

\section{Kesimpulan}

Dalam penelitian ini ditemukan informasi bahwa belum adanya penerapan sistem proteksi kebakaran di gedung sekolah SDN 09 Makasar. Padahal sistem proteksi kebakaran ini dapat melindungi sarana dan prasarana pendidikan di sekolah tersebut. Selain untuk melindungi sarana dan prasarana sekolah, sistem proteksi kebakaran juga digunakan untuk melindungi anak yang menjadi siswa sekolah karena siswa sekolah dasar merupakan anak yang termasuk dalam golongan usia rentan yang menjadi prioritas utama dalam penangan bencana. Belum adanya pelatihan penerapan proteksi kebakaran dan juga program sosialisasi proteksi kebakaran di SD 09 Makasar Jakarta akan semakin meningkatkan kondisi rentan pada siswa yang menjadi anak didik di sekolah tersebut.

\section{Saran}

Dalam rangka menunjang penerapan sistem proteksi kebakaran di gedung sekolah maka perlu dilakukan program untuk pengelolaan proteksi kebakaran yang dilakukan oleh pihak Pemda DKI secara berkesinambungan. Program ini nantinya akan digunakan untuk meningkatkan perlindungan terhadap siswa sekolah yang menjadi kelompok rentan bencana kebakaran karena anak-anak seringkali menjadi korban terbesar dalam setiap kejadian bencana karena ketidakmampuannya melindungi diri, apabila anak-anak berada diluar jangkauan pengawasan orangtuanya. Selanjutnya untuk penelitian yang akan datang diharapkan dapat membuat sebuah model sistem proteksi kebakaran yang tepat untuk diterapkan di sekolah-sekolah di wilayah DKI Jakarta.

\section{Daftar Pustaka}

1. Badan Standarisasi Nasional SNI 04-0225-2000. Persyaratan Umum Instalasi Listrik, Jakarta: Yayasan PUIL. 2000

2. Deny Andrias. Lima Tahap Bangunan Gedung untuk Mendapatkan SLF. 2019. https://www.jakartafire.net/.

3. Nur Aini. Panel Listrik di Sekolah Rawamangun Terbakar Akibat Korsleting. 2019. https://ntmcpolri.info/

4. Undang-Undang Republik Indonesia No. 24 Tahun 2007, tentang Penanggulangan Bencana.

5. Peraturan Menteri Pekerjaan Umum, Nomor 26/PRT/M/2008, tentang Persyaratan teknis sistem proteksi kebakaran pada bangunan gedung dan lingkungan.

6. Arif Kurniawan. Gambaran Manajemen dan Sistem Proteksi Kebakaran di Gedung Fakultas Kedokteran dan Ilmu Kesehatan UIN Jakarta Tahun 2014. 2014.http://repository.uinjkt.ac.id/dspace/handl e/123456789/25569.

7. Fatma Lestari (dkk). Kajian Keselamatan Kebakaran pada Lima Sekolah Dasar di DKI Jakarta. Jurnal Kesehatan Masyarakat Nasional Vol. 6, No. 1, Agustus 2011.

8. Sugiyono. Metode Penelitian Kuantitatif, Kualitatif dan R\&D. Bandung: Afabeta. 2011.

9. Aswin Bancin dan Wildansyah Lubis. Manajemen Sarana dan Prasarana Pendidikan. 2017. EducanduM Volume: X Nomor: 1 Edisi: Juni 2017. 
10. Juli Sapitri Siregar dan Adik Wibowo. Upaya pengurangan risiko bencana pada kelompok rentan. Jurnal Dialog Penanggulangan Bencana, 30-38. 2019. https://bnpb.go.id/uploads/24/jurnal-vol-10-no1-tahun-2019-revisi-final-1.pdf

11. Soehatman Ramli. Pedoman Praktis Manajemen Bencana (Disaster Management). Dian Rakyat: Jakarta. 2010.

12. Suharsimi Arikunto. Prosedur Penelitian Suatu Pendekatan Praktik. Jakarta: Rineka Cipta. 2016.

13. Tri Mariyatin. Penilaian Resiko Bahaya
Kebakaran Pada Gedung Bertingkat (Studi di MI Terpadu Ibnu Sina Kecamatan Kembang dan MA Hasyim Asy'ari Kecamatan Bangsri Kabupaten Jepara). 2017 http://repository.unimus.ac.id/id/eprint/1100.

13. Atmojo M.E. Pendidikan Dini Mitigasi Bencana. J Abdimas BSI J Pengabdi Kpd Masy. 2020;

14. Arief Kurniawan. Gambaran Manajemen Dan Sistem Proteksi Kebakaran Di Gedung Fakultas Kedokteran Dan Ilmu Kesehatan Universitas Islam Negeri Jakarta Tahun 2014. UIN. 2014. 